\title{
WAAM Application for EPC Company
}

\author{
Priyantomo Agustinus Ananda ${ }^{1}$ \\ ${ }^{1}$ QA/QC Department of PT Rekayasa Industri, Kalibata Timur I No 36, Jakarta, Indonesia
}

\begin{abstract}
WAAM ( Wire + Arc Additive Manufacturing) is a process of adding material layer by layer in order to build a near net shape components. It shows a further promising future for fabricating large expensive metal components with complex geometry. Engineering Procurement and Construction (EPC) company as one of the industrial section which related with engineering design and products, wide range of material type, and shop based or site based manufacturing process have been dealing with conventional manufacturing and procurement process in order to fulfill its requirement for custom parts and items for the project completion purpose. During the conventional process, there is a risk during the transportation of the products from the manufacturing shop to then site project, this risk is even greater when the delivery time take part as one of the essential part which affect the project schedule. Wire Arc Additive Manufacturing process offering an alternative process to shorten the delivery time and process for a selected material and engineered items, with the consideration of essential variables which can affect the final products of WAAM process, such as : heat input, wire feed speed, travel speed, shielding gas, welding process and robotic system applied. In this paper, the possibilities of WAAM application in EPC company will be assessed, an in depth literature review of the various process which possible to applied, include the loss and benefit compared with conventional method will be presented. The main objective is to identify the current challenge and the prospect of WAAM application in EPC company.
\end{abstract}

\section{Introduction}

The fabrication process development in EPC (Engineering, Procurement, and Construction) company is mainly drive by three factors:

1. Quality

2. Time

3. Cost

Which shall be implemented in the project through two processes [1].

1. Project management processes, a process to ensure the flow of effective added value during the work cycle.

2. Product oriented process, a process to ensure product based on specification.

Through this principles, the EPC process (from here shall be named project) have been through the standard operation procedure which include design the items and components, which has been customized and non-mass produced, procured, transported and erected in the site of project. The conventional process of these design-purchase-erected workflow system has been adopted since the beginning of the company in 1980's
[2]. Since the projects are dealing with customized product, problems related with the lead time process often risen. The lead time is the time which will measure the quantitative time needed from design engineering phase to the construction phase.

\section{EPC Process Aspects}

\subsection{Working Structures}

Acting as the contractor, EPC Company has an obligation to accomplish the project which is initiated by the owner or also may called as company. Projects shall be done under the regulations and requirements which has been agreed between the owner and contractor prior to the contract signed. Defined by the services which may an EPC company offered, it can be breakdown as these services [3]:

1. Engineering Services (E): basic and detailed engineering services.

2. Purchasing (P): Purchasing, expediting, shipping \& transportation of the equipment/material.

3. Construction and commissioning $(\mathrm{C} \& \mathrm{C})$ : multi disciplines construction works

4. Project Management Consultancy Services

5. Operation and maintenance 
From these services type, EPC's project specified into 4 types of projects [3] :

1. Grass root projects

2. Revamping projects

3. Expansion projects

4. Relocation projects

These various type of services and projects which may be undertake by the EPC company shaped the working structure of the company, seldom referred as project contract structure. A conventional EPC company would have a structure as in figure 1

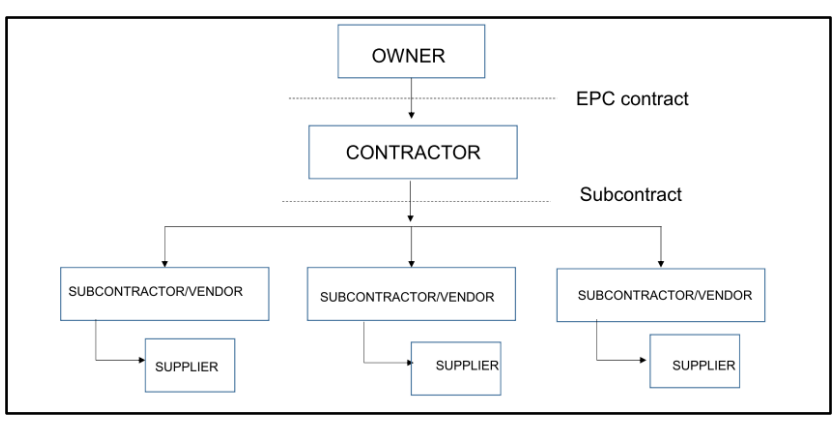

Fig 1. Working Structure

\subsection{Project Life Cycle}

The project as it started to run in the effective schedule, developed phases of work which explained the stage of work in the project, the related department who become the responsible person, and main activity which shall be accomplished. The phases in the project are described in the figure 2

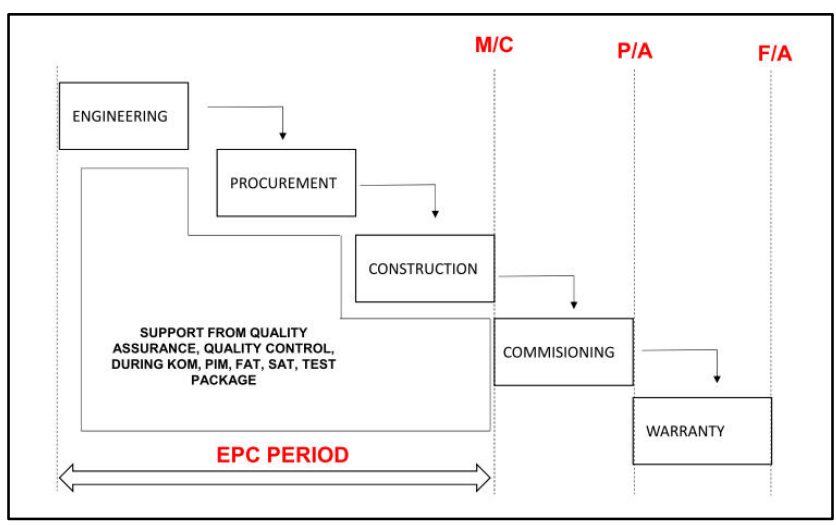

Fig 2. Project Phase

The flow process in EPC starts from engineering phase which provided the design, detail drawing, and MTO. Then during procurement phase, vendors and subcontractors were awarded and assigned in order to supply materials for construction, as well as construction and erection services. However, during construction phase, there are possibilities of change in design and resulted in as built drawing or revision following the actual condition in the site [3]. Whenever the change in design occurred, the process of material/item procurement process will be started again from the beginning which will affect the lead time and schedule. The flow process for item/material procurement is shown in figure 3 [1].

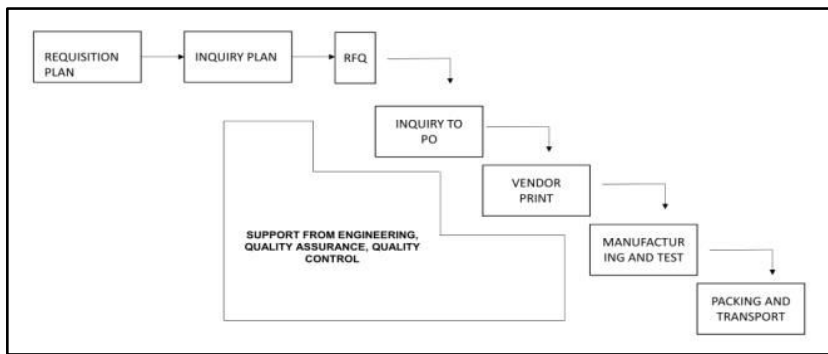

Fig 3. Procurement flow process

\section{WAAM Technology Features}

\subsection{WAAM History}

The WAAM (Wire + Arc Additive Manufacturing) is a part of AM (Additive manufacturing) process has been an area for research since the mid-1980's. Earlier this technology was focused on just rapid prototyping by transferring CAD models in. STL files figures 4

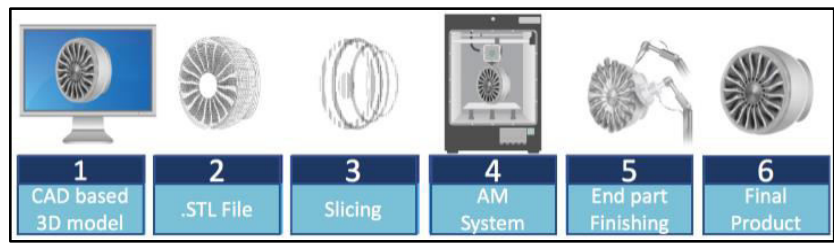

Fig 4. AM proces [4]

However, from the past decade, it is being recognized for its various possibilities and advantages. While machining parts using traditional or subtractive manufacturing methods, a scrap rate as high as $80 \%$ to $90 \%$ is produced. Whereas, with AM technologies, the part is built with minimal machining and the desired geometry is produced with a low scrap rate $(>10 \%)$, which will give a great benefit, especially for the Lean Manufacturing concept which aims for build the project while maximizing value, minimizing waste and pursuing perfection [5] and better cost efficient for valuable material such as Titanium. The diagram for AM family is shown in figure 5 .

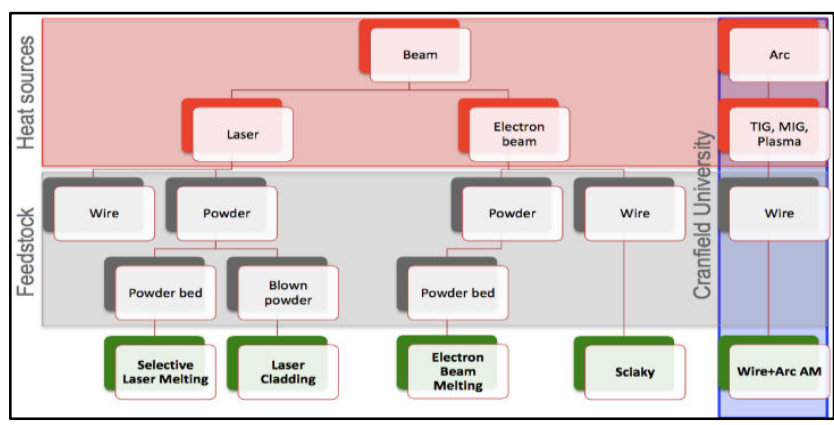

Fig 5. Diagram of AM [4] 
Martina et al [6]. Described the WAAM stands for Wire + Arc Additive Manufacturing as the novel AM (Additive Manufacturing) process which offers significant strategic advances. Its process of building 3D metallic components by depositing weld beads one above the other in a layer by layer fashion, which resulted in a straight metallic wall with a minimum width of 1-2 mm, including the "waviness" [6]. The basic configuration for WAAM is shown in figure 6 .

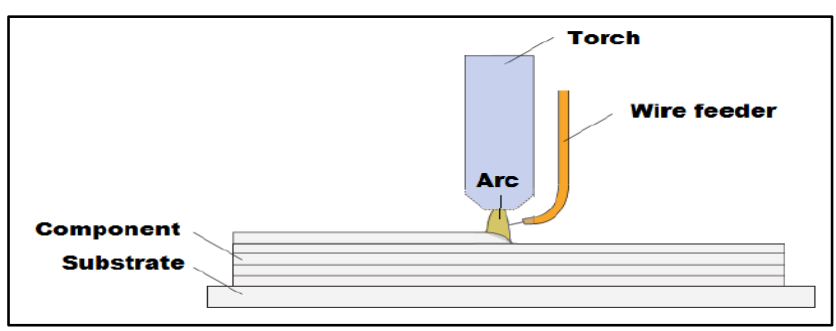

Fig 6. WAAM basic configuration [7]

\subsection{Process Descriptions}

As described in the figure 5, the WAAM process, as in AM process, has the main items in Heat Sources and Feedback system. The heat Sources, in the WAAM is generated from the arc produced by one of these three welding process: TIG, MIG, and Plasma. These welding processes are most applicable when working with the motion system which can be 6 axis robot or gantries CNC (Computer Numerical Control) controlled as shown in figure 7.

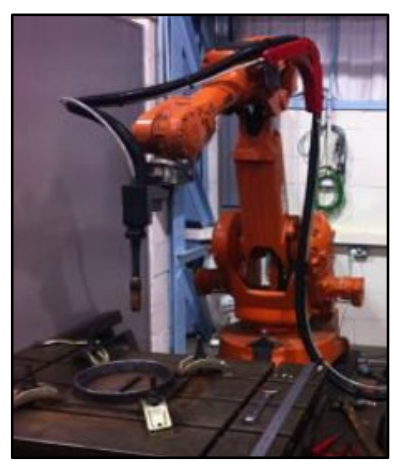

Fig 7. 6 axis robot [4]

Differ from other AM system such as Selective Laser Melting (SLM) and Laser Cladding (LC) which based on laser as the heat sources and Electron Beam Melting (EBM) which based on electron beam, these systems also utilize powder and wire as the feedstock. WAAM utilized only wire as its feedstock, and the common welding process such as GMAW (Gas Metal Arc Welding), GTAW (Gas Tungsten Arc Welding), or using the more sophisticated PAW (Plasma Arc Welding) as the heat sources. In relation with the parameter which applied to the welding system, WAAM has been proven to be more cost effective from equipment setup, production speed, and the availability in the remote area. However, the accuracy of powder based feedstock is still beyond the wire based system until present time, the comparison of different AM system is shown in table 1.

Table 1. Comparison of AM processes [4]

\begin{tabular}{|l|c|c|c|c|c|}
\hline & $\begin{array}{l}\text { Deposition } \\
\text { rate }(\mathbf{k g} / \mathbf{h})\end{array}$ & $\begin{array}{l}\text { Time of } 1 \text { ton } \\
\text { processing }\end{array}$ & Accuracy & $\begin{array}{l}\text { Equipment } \\
\text { cost }\end{array}$ & Feedstock \\
\hline SLM & 0.2 & 7 months & $25 \mu m$ & $>£ 300 \mathrm{k}$ & Powder \\
\hline LC & 1 & 41 days & $25 \mu m$ & $£ 1 M$ & Powder \\
\hline EBM & 0.2 & 7 months & $25 \mu \mathrm{m}$ & $£ 500 \mathrm{k}$ & Powder \\
WAAM & Up to 10 & 4 days & $1-2 \mathrm{~mm}$ & $£ 200 \mathrm{k}$ & Wire \\
\hline
\end{tabular}

\subsection{Product Characteristics}

The product of WAAM is a 1-2 mm minimum thickness of metallic wall. This thickness includes the "waviness" as the result of the welding process, which need to be machined. The length remained after the machining process is called the Effective Wall Width or also identified as Effective Wall Thickness (EWT) [8]. The wall characteristics is described in figure 8 .

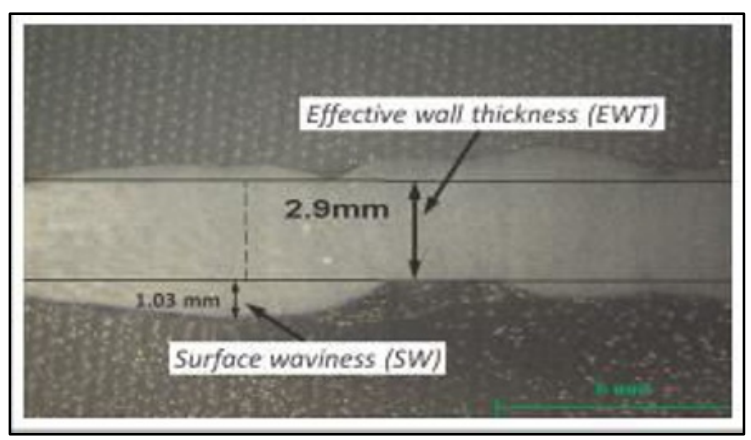

Fig 8.Effective Wall Thickness [8]

This characteristics of products allows near net shape or net shape manufacturing with a better tolerances for design complexity. Parts for critical use has been developed using Additive manufacturing method which include the WAAM process, some of the parts are shown in figure 9-10.

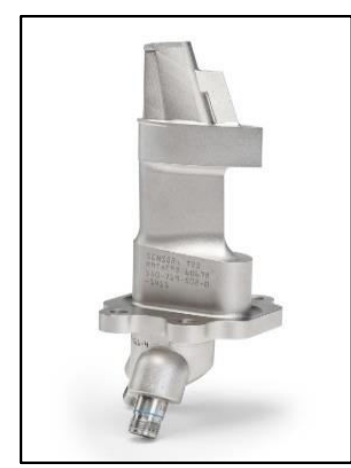

Fig 9. T25 housing for sensor for Boeing 777 [9] 


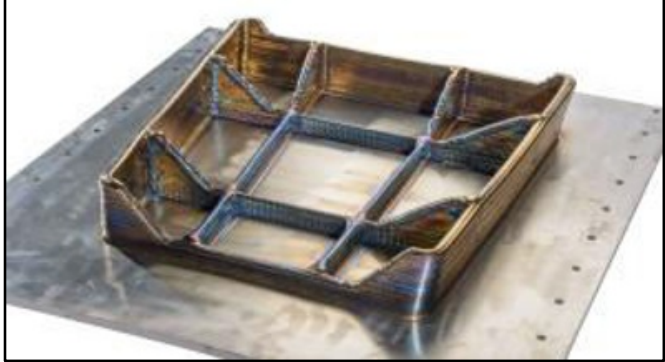

Fig 10. Bombardier landing gear rib [4]

\section{Discussion}

\subsection{Applications in EPC process}

Busachi et al. [6] described that manufacturing system for WAAM is relatively simple and compact it could accommodate the place where space is limited, the outline for complete process map for WAAM system is shown in figure 11. It is the minimum specification needed to convert geometry data into a functional parts.

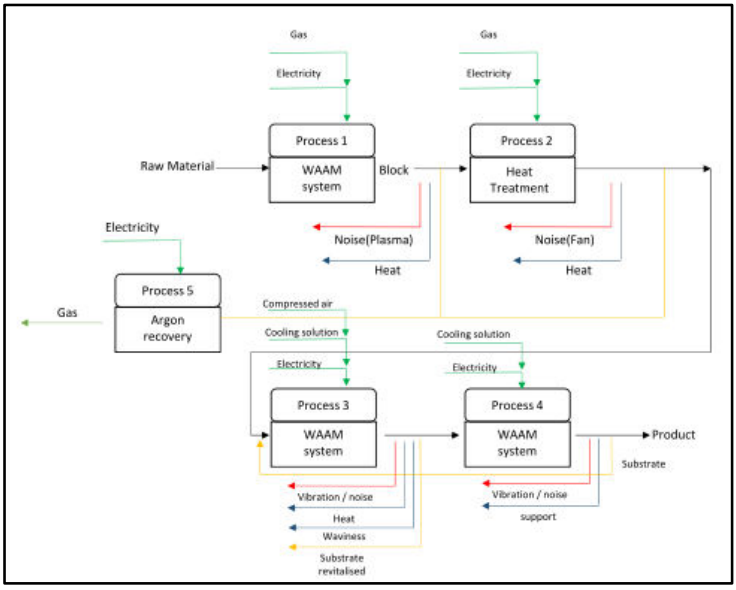

Fig 11. WAAM basic configuration [6]

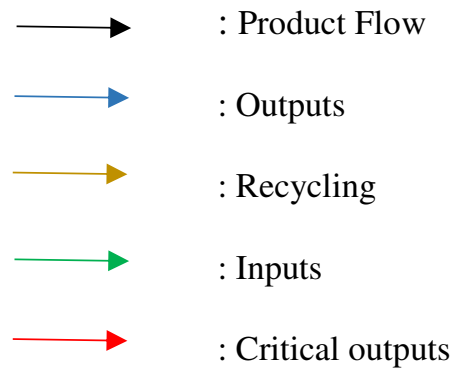

For the transfer information, there are two possible ways for the application:

1. Online route: the fabrication process is conducted real time with the coordination between Head Office (HO) and Site Office (SO). The design and material selection is based on the database and the data communicate between the productions units in the site through internet connection. The connection map is shown in figure 12 .

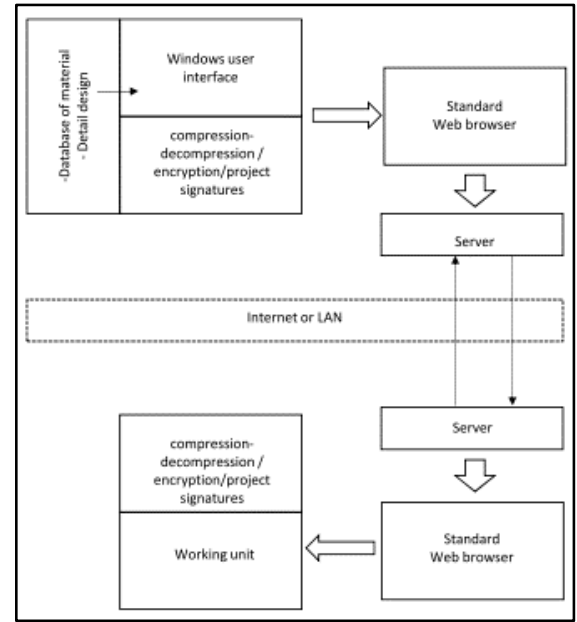

Fig 12. Online process map [10]

Although the system may be executed as a real time process, the main concern of this mode is the lag of time during process cause by the stability of the internet connection which can cause the issue to the product's quality because of the welding sequence which need to be maintained.

2. Manual route : the fabrication process and the design process take separate location, which means the data (design) is not executed real time and the basic configuration as in figure 11 is producing the parts as per data previously designed by the engineers prior to production process.

\subsection{Benefit of WAAM}

\subsubsection{Economics point of view}

Boubekri et al [11] have described the economics benefit of Additive Manufacturing process, which include the WAAM process. Among the description, the economic benefit of WAAM may be listed as below:

1. Less Waste, using the additive manufacturing process, only the amount of raw material necessary is used in the designed parts.

2. No tooling cost, research of Jens et al [12] stated that $93,5 \%$ of the traditional manufacturing cost structure is linked to tooling. 
3. Smaller production cost, 3D printing (in this case is $\mathrm{AM}$ ) is suitable for manufacturing small quantities, parts which not feasible when mass produces, but not possible made by hand [13].

4. Large scale customization, variety and complexity may be achieved using the AM technology.

5. Eliminates lead time, AM eradicates the time for retooling, a new design parts may be produced after the previous part finished. This allow the company to do manufacturing on demand [11] .

\section{BTF (Buy To Fly) ratio}

$$
\text { BTF : } \frac{\text { Mass initial }}{\text { Mass final }}
$$

Ratio which defined the quantity of material needed for each weight $(\mathrm{kg})$ which actually wasted (flies) [4].

\subsubsection{Application point of view}

As described in the previous paragraphs, the WAAM has advantages compared with the conventional method such as subtractive manufacturing method, it facilitate the need of complex geometry, non-mass production items, parts which have high customization, and parts with expensive material (such as titanium) [14]. Flexibility of design is accommodated with this process, which include several of angle and shape. Basic shape such as line, curve, box and intersection have been developed as some of the example shown in figure 13.

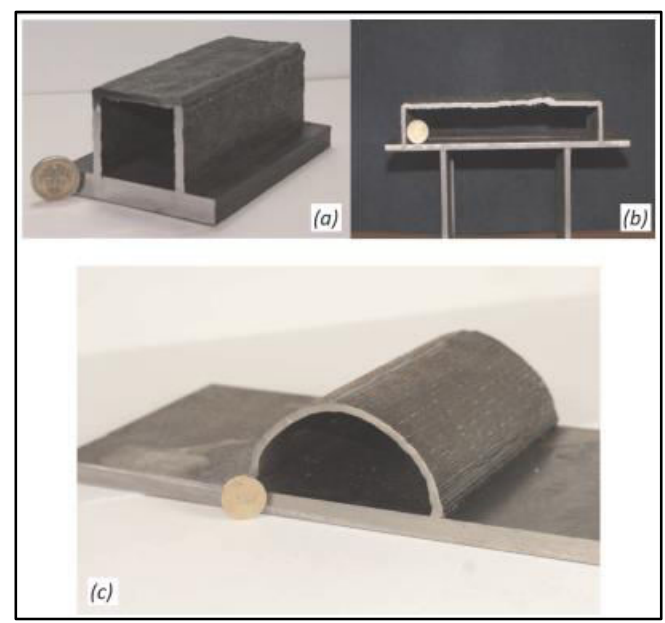

Fig 13. (a) $50 \mathrm{~mm}$ square section, (b) $200 \mathrm{~mm}$ overhang, (c) $50 \mathrm{~mm}$ radius semicircle [8]
The reductions of BTF or Buy To Fly Ratio as described in paragraph 4.2.1 has significant effects in relations with material to be used and the material cost. Reduction in BTF ratio will reduce the cost for parts production as described in Table 2.

Table 2. Comparison between conventional and WAAM [4]

\begin{tabular}{|c|c|c|c|c|c|}
\hline \multicolumn{2}{|c|}{\begin{tabular}{|c|c|} 
Parts & Bombardier \\
Manufacturing Option \\
\end{tabular}} & \multirow{2}{*}{$\begin{array}{l}\text { anding Grip } \\
\text { Mass (Kg) }\end{array}$} & \multirow{2}{*}{\begin{tabular}{|l|} 
Material \\
BTF \\
\end{tabular}} & \multirow{2}{*}{\begin{tabular}{|l|} 
Titanium \\
Cost (fK) \\
\end{tabular}} & \multirow{3}{*}{\begin{tabular}{|c|} 
Cost red \\
-
\end{tabular}} \\
\hline \multicolumn{2}{|c|}{ Manufacturing Option } & & & & \\
\hline Original & Machined & 20 & 12 & 16.2 & \\
\hline Original & WAAM & 20 & 2.3 & 5 & $69 \%$ \\
\hline
\end{tabular}

For EPC projects, the best way to simulate the possibilities which can be exploit from WAAM is to compare the fabrication of piping package especially for the "exotic" material such as CRA (Corrosion Resistance Alloy). During the construction phase of EPC projects, the change in piping line for length, dimension, elevation, best described as "As Build" may require a specific dimension of pipe spool which may not be covered in original purchasing. Piping products come in specific length such as 6,9 , or 12 in metres and unable to purchase it in custom specification since there is a minimum quantity which need to fulfilled or else the price will not be feasible for the budget, excluding the deviation in project schedule for the delivery process. The simulation sample will be pipe welded CS package, and the length needed in the site is 1 meters only. The estimation is shown below excluded the facilities set up for WAAM process.

Table 3. Comparison between conventional and WAAM in piping package [Rekayasa Industri's database]

\begin{tabular}{|l|c|c|c|c|c|c|c|c|}
\hline Parts & \multicolumn{2}{|c|}{ Pipe Welded CS } & Material & \multicolumn{5}{|c|}{ CS } \\
\hline \multicolumn{2}{|l|}{ Manufacturing Option } & $\begin{array}{c}\text { UNIT PRICE PER TON } \\
\text { (USD) }\end{array}$ & $\begin{array}{c}\text { Length } \\
\text { Available }\end{array}$ & Unit & $\begin{array}{c}\text { Length } \\
\text { Actual }\end{array}$ & Unit & Cost(USD) & $\begin{array}{c}\text { Cost } \\
\text { Reduction } \\
\text { (USD) }\end{array}$ \\
\hline Original & Machined & 1109.31 & 6 & $M$ & 1 & $M$ & 204.89 & - \\
\hline Original & WAAM & 1109.31 & Custom & $M$ & 1 & $M$ & 34.15 & $83.33 \%$ \\
\hline
\end{tabular}

Compared with the conventional process, WAAM is estimated to show its full potential on pipe spool/fitting case which often came with custom dimension and limited numbers, and can be done in 24 hours for specific pipe diameter and schedule.

\subsubsection{Supply Chain point of view}

Huang, S.H et al. [15] Indicated the serious impact which resulted from AM technology is the supply chain management, with its ability to build products near customer and with fewer components. This also 
include reducing the need of warehousing for inventory, transportation, time to market and lead time.

\subsection{Challenge of WAAM}

\subsubsection{Tensile properties limitation}

The research of Geng H, et al. [16] indicated that there are restrictions for the tensile properties of WAAM product, two set of specimens were taken from the sample (products) of deposited 5A06 Aluminium Alloy. The first set of specimen taken based on build direction (Hd : parallel to build direction, Pd: perpendicular to build direction) and the second set of specimen were taken based on solidification texture (Ht : parallel to solidification texture, $\mathrm{Pt}$ : perpendicular to solidification texture) figure 14. The experiment resulted in the specimen related with build direction the tensile test result show isotropy both parallel and perpendicular, meanwhile the test result for texture orientation showed anisotropy result.

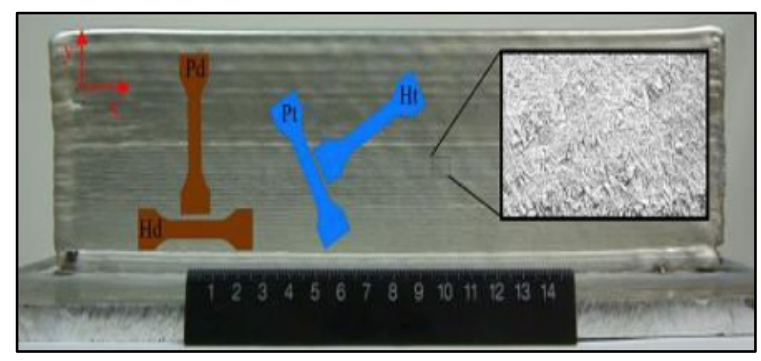

Figure 14. Specimen orientation [16]

\subsubsection{Quality Standard consideration}

For the products which will be applied to EPC projects which engaged with strict regulation and standards, WAAM products need to have a proper qualifications and standard regulation which will satisfy the requirement of the clients. Busachi et al. [6] stated that the detailed procedures for the quality assurance (QA) of the process has been missing in some of the international standard such as American Society of Mechanical Engineering (ASME). However, Martina [17] explained that the current method for quality assurance purpose are:

1. Neutron diffraction and contour method to measure residual stress

2. Radiography test (RT)/ Ultrasonic test (UT) for subsurface defects

Although the qualification of the AM especially for critical application facing challenges on its development, the efforts for this challenge has been done. For example ASTM F42 committee and SAE who have released several standards on AM [18]. The list of current standards for testing the AM material is listed but not limited on table 4 .

Table 4. Testing Standard list [19]

\begin{tabular}{|c|c|l|}
\hline No & Standard & \multicolumn{1}{|c|}{ Description } \\
\hline 1 & AFNOR XP E67-030: 2013 & $\begin{array}{l}\text { Additive Manufacturing. Parts made by additive } \\
\text { manufacturing. Specifications and acceptance test }\end{array}$ \\
\hline 2 & ASTM F2971: 2013 & $\begin{array}{l}\text { Standard practice for reporting data for test } \\
\text { specimens prepared by additive manufacturing }\end{array}$ \\
\hline 3 & ASTM F3122: 2014 & $\begin{array}{l}\text { Standard guide for evaluating mechanical properties } \\
\text { of metal materials made via additive manufacturing } \\
\text { processes }\end{array}$ \\
\hline
\end{tabular}

\section{Conclusion}

WAAM process application for EPC Company has offered an alternative solution for its production process, which often have a condition of remote site area, limited road connection which affected the supply and logistic activity, and possibilities of high customization non mass production parts. With its ability to develop a production facility on site and able to controlled from the head office, a custom part may be produced in the site to accommodate the needs of the project completion. However, few concerns of this process is in the need of further study in order to seize the customer's trust of the product. The item of concerns are listed below:

1. Standard applicable for WAAM, especially for the test (either Destructive test or Nondestructive test), which can be referred in the Client's project requirement and described in the project specification for the EPC (contractor) company to follow.

2. Further study of the structural integrity of the fabricated parts using WAAM and using conventional method.

3. Feasibility study for the equipment cost for different type of project which stated in the paragraph 1.1

\section{References}

1. Yus R Soepandi. Manajemen Proyek EPC. Jakarta : Rekayasa Industri (2014).

2. Industri, PT Rekayasa. Kisah kisah membangun industri di Indonesia. Kisah kisah membangun industri di Indonesia. Jakarta: PT Rekayasa Industri (2007).

3. EPC Project Management. Radian, Hosen. Jakarta :PT Rekayasa Industri (2008). 
4. Additive Manufacturing. Martina, F and McAndrew, A. Cranfield : Cranfield University (2016).

5. Pinch, Lauren. Lean construction : eliminating the waste. Construction executive. Washington D.C : The YGS group (2005).

6. Designing A WAAM Based Manufacturing System for Defence Applications. Busachi, Alesandro, et al. Cranfield: Elsevier, CIRP 37( 2015 ) 48 - 53 (2015) .

7. Priyantomo, Agustinus, et al. ADDITIVE MANUFACTURING OF TITANIUM ALLOY COMPONENTS USING A LOCAL SHIELDING DEVICE. Cranfield : Cranfield University (2017)

8. Fabrication of geometrical features using Wire and Arc Additive Manufacturing. Kazanas, Panagiotis, et al. Cranfield: Journal of Mechanical Engineering, Vols. 226(6) 1042-1051 (2012). $10.1177 / 0954405412437126$.

9. Kellner, Thomas. www.ge.com. [Online] General Electrics, April 14, 2015. [Cited: March 5, 2018.] https://www.ge.com/reports/post/116402870270/th e-faa-cleared-the-first-3d-printed-part-to-fly-2/ (2015)

10. Suprifesi. Welding Monitoring System. Jakarta : PT Rekayasa Industri (2018)

11. Economics of Additive Manufacturing . Boubekri, Nourredine and Alqahtani, Meshari. 1, s.l.: International Institute of Engineers, Vol. 2. ISSN 2349-1485 (2015)

12.Analyzing Product Lifecycle Costs For A Better Understanding of Cost Drivers In Additive Manufacturing. Pottebaum, Jens, Lindemann, Christian and Koch, Rainer. University of Texas : proceedings of the 23rd Annual International Solid Freeform Fabrication Symposium (2012)

13.Makers-The New Industrial Revolution. Anderson, Chris. London: Random House Business Books (2012)

14.Additive Manufacturing Technology: Potential Implications for U.S. Manufacturing Competitiveness. Ford, Sharon L N. Washington : Journal of International Commerce and Economics, Vol. http://www.usitc.gov/journals (2014)

15. An Economic Insight into Additive Manufacturing System Implementation. Pour, Milad Ashour, et al. Brescia, Italy: IFIP International Federation for Information Processing, Vols. APMS 2015, Part II, IFIP AICT 460, pp. 146-155. 10.1007/978-3-31922759-7_17 (2015)

16.Geometric Limitation and Tensile Properties of Wire and Arc Additive Manufacturing 5A06 Aluminum Alloy Parts. Geng, Haibin, et al. Xian, China: Journal of Materials Engineering and Performance; ASM International, Vols. 26 (2) pp 621-629. 10.1007/s11665-016-2480-y (2016)

17.Investigations of methods to manipulate geometry,microstructure and mechanical properties in titanium large scale Wire+Arc Additive Manufacturing. Martina, Filomeno. Bedford: Cranfield University,Vol. PhD Thesis (2014).

18.Metal Additive Manufacturing: A Review. Frazier, William E. 4, Patuxent River : Journal of Materials Engineering and Performance; ASM International,Vol. 23. 10.1007/s11665-014-0958-Z (2014).

19. TWI. www.twi-global.com. [Online] October 2016. https://www.twi-global.com/technicalknowledge/faqs/faq-standards-used-for-additivemanufacture/ (2016) 